\title{
Antimicrobial action of methanolic seed extracts of Syzygium cumini Linn. on Bacillus subtilis
}

\author{
Alok Kumar Yadav, Saurabh Saraswat, Preeti Sirohi, Manjoo Rani, Sameer Srivastava, Manish Pratap Singh \\ and Nand K. Singh*
}

\begin{abstract}
Phytochemicals of Syzygium cumini are used for the treatment of various diseases as a traditional medicine but the mechanism behind their action is not well reported. Antimicrobial activity of methanolic seed extract of $S$. cumini was done by agar well diffusion assay on Bacillus subtilis and its zone of inhibition was found to be $20.06 \mathrm{~mm}$ in comparison to control having no zone of inhibition. MIC of S. cumini was found to be $0.3 \mathrm{mg} / \mathrm{ml}$. Genomic DNA degradation of B. subtilis reveals apoptosis and FE-scanning electron microscope indicates cell wall cracking on several intervals of time. Results of propidium iodide staining showed few bacterial cells were stained in control; however population of stained cells increased after exposing them for varying period of time. Flow cytometric kinetic data analysis on the membrane permeabilization in bacterial cell showed the significant contribution of antimicrobial potential of the seed extract on antimicrobial-induced permeabilization. In silico analysis revealed two components of S. cumini methanolic extract to be active against four enzymes (PDB ID—1W5D, 4OX3, 3MFD and 5E2F) which are crucial for plasma membrane synthesis in B. subtilis. Moreover lupeol showed highest binding energy for macromolecule 1W5D and 4OX3 forming one hydrogen bond each whereas stigmasterol showed the highest binding energy for macromolecule 3MFD and 5E2F forming four hydrogen bonds and alkyl bonds respectively. It demonstrates that methanolic seed extracts of $S$. cumini could be used for inhibition of food born infection caused by B. subtilis and also an alternative of prevalent antibiotics.
\end{abstract}

Keywords: Syzygium cumini, Antimicrobial, Inhibition, Bacillus subtilis

\section{Introduction}

Antibiotic resistance in microorganisms is the major problem in all over the world both in developing as well as developed nations. The antibiotic resistance in bacteria has made it difficult to control some food born infections. The emergence of antimicrobial resistance in bacteria against certain antibiotics has challenged researchers to find some alternatives for avoiding this problem. Syzygium cumini are rich in herbal active constituents which have many antimicrobial compounds and could be suggested as an alternative to this problem. Syzygium cumini is widely used medicinal plant in herbal medicines due to

\footnotetext{
*Correspondence: singhnand@gmail.com

Department of Biotechnology, Motilal Nehru National Institute of Technology, Allahabad, UP 211004, India
}

its vaunted property. Its biological efficiency are noticed as antihyperglycemic, anti-inflammatory, antibacterial, cardioprotective and antioxidant (Kumar et al. 2008; Rekha et al. 2008; Sharma et al. 2008; Tanwar et al. 2011; Mastan et al. 2009; Arun et al. 2011; Tanwar et al. 2011). The antimicrobial activity of $S$. cumini seed extract is effective against Bacillus subtilis as these are reported cause food borne illness (Kramer and Gilbert 1989; Drobniewski 1993). The B. subtilis strains are found responsible for ropiness in spoiled bread dough (Kirschner and von Holy 1989; Collins et al. 1991). While some of them are also found to be causative agent for septicaemia in immunocompromised patients (Oggioni et al. 1998). Retrospective studies have shown that $B$. subtilis has evolved antibiotic resistance and produces heat stable toxins amylosins (Richard et al. 1988; Apetroaie-Constantin 
et al. 2009). Furthermore B. subtilis, B. anthracis and B. thuringiensis have spores that protect them from various adverse conditions and found that molecular iodine is quite effective in killing of its spore (Li et al. 2016). In present article the underlying mechanism behind the antimicrobial potential of methanolic seed extract of $S$. cumini on B. subtilis is revealed.

\section{Materials and methods}

\section{Collection of $S$. cumini fruits and extract preparations}

Syzygium cumini seeds were obtained from orchard of Motilal Nehru National Institute of Technology, Allahabad. Collected seeds were washed in distilled water for about $15 \mathrm{~min}$. Washed seeds were dried completely in an oven at $60{ }^{\circ} \mathrm{C}$ for $2-3$ days to remove water content and grinded into fine powder. The dried fifteen grams powder of $S$. cumini seed was filled into the thimble and subjected to soxhlet extraction using methanol as solvent and isolated seed extract was concentrated by rotary evaporator. Concentrated extract was dissolved in PBS making a final concentration of $25 \mathrm{mg} / \mathrm{ml}$ for use in further study.

\section{Culture of B. subtilis MTCC 2413}

Bacillus subtilis MTCC 2413 strain was obtained from Microbial Type Culture Collection (MTCC), Institute of Microbial Technology, Chandigarh, India. The culture of B. subtilis 2413 was grown in LB broth after transferring few amount of lyophilized powder in it. The broth was kept at $37{ }^{\circ} \mathrm{C}$ inside shaking incubator for overnight at $120 \mathrm{rpm}$ as per the recommendation. The overnight culture of B. subtilis MTCC $2413(\mathrm{CFU} \mathrm{10} / \mathrm{ml})$ was used for subsequent study.

\section{Antibacterial assays}

The antibacterial activity of $S$. cumini Linn. was done by using agar well diffusion assay (Valgas et al. 2007). The $B$. subtilis MTCC 2413 was poured on agar plate and spread properly then allowed the culture to stable for about 20-30 min. After drying the wells were made and poured with $300 \mu \mathrm{l}$ methanolic seed extracts of S. cumini Linn. Then plates were kept inside an incubator for overnight interval at $37^{\circ} \mathrm{C}$ in an appropriate condition. Antimicrobial activity of methanolic seed extracts of S. cumini was determined by measuring zone of inhibitions using PBS as negative control. All the experiments were performed in triplicate.

\section{Minimum inhibitory concentration (MIC)}

The minimum inhibitory concentration (MIC) of methanolic seed extract of $S$. cumini was determined by Clinical and Laboratory Standards Institute-(CLSI) recommended broth microdilution assay with few modifications. The methanolic seed extract was made in between
0.1 and $2.0 \mathrm{mg} / \mathrm{ml}$. The microtiter plate were inoculated with $100 \mu \mathrm{l}$ of bacterial culture and treated with prepared dilution of methanolic seed extract of S. cumini and overnight incubation was given at $37{ }^{\circ} \mathrm{C}$. The absorbance was measured at $600 \mathrm{~nm}$ using microtiter plate reader to access the cell growth. The negative control was taken as LB broth bacteria suspension without any agent and blank as only medium and positive control as medium with agents. The MIC was calculated at lowest concentration at which it inhibits the growth of bacteria. All these experiments were performed in triplicate.

\section{Cell viability assessment by fluorescence microscopy}

The B. subtilis cells were further stained with propidium iodide (PI), a nucleic acid staining dye and analysed by florescent microscope. The Bacterial cells were isolated from culture flask and centrifuged at $7000 \mathrm{rpm}$ for $10 \mathrm{~min}$ at $4{ }^{\circ} \mathrm{C}$ to pellet down the cells. The cells were washed twice a time with phosphate buffer saline (PBS). The washed cells were fixed with $3.7 \%$ paraformaldehyde in PBS for $20 \mathrm{~min}$ at room temperature and then washed with cold PBS, and added propidium iodide. After adding Propidium iodide the cells were spread on the glass slide and covered by cover slip and observed by fluorescent microscope.

\section{Membrane permeabilization by flow cytometric analysis}

To reveal the mechanism behind antibacterial activity of methanolic seed extract of S. cumini, and its ability to permeabilize bacterial membrane was done by PI uptake assay (Tyagi et al. 2015). Briefly B. subtilis was grown in LB agar media and treated with seed extract of S. cumini for 24, 48 and $72 \mathrm{~h}$ and kept in an incubator at $37^{\circ} \mathrm{C}$ respectively. After every equal interval cells were harvested and washed twice with PBS, stained with Propidium iodide (PI) and incubated for $20 \mathrm{~min}$ in dark. The PI fluorescence was measured using flow cytometer. A total of 10,000 cells were taken for each flow cytometric analysis.

\section{Cells surface characterization by field emission scanning electron microscope}

The field emission scanning electron microscope (FESEM) was performed to examine the morphological changes in B. subtilis MTCC 2413 strain after treatment with methanolic seed extract in varying time interval viz. 24, 48 and $72 \mathrm{~h}$. Bacterial cells were centrifuged at $6000 \mathrm{rpm}$ for $10 \mathrm{~min}$ to settle down the bacterial pellet. The bacterial pellets were washed twice in phosphate buffer saline (PBS) at $5000 \mathrm{rpm}$ for $5 \mathrm{~min}$. Washed bacterial pellet were fixed in $2.5 \%$ glutaraldehyde solution for $1 \mathrm{~h}$. Fixed bacterial pellet were again washed with phosphate buffer saline (PBS) at $5000 \mathrm{rpm}$ for $5 \mathrm{~min}$. Washed 
bacterial pellet was dehydrated in series of $10,20,30,40$, $50,60,70,80,90$ and $100 \%$ ethanol for $10 \mathrm{~min}$ at $37^{\circ} \mathrm{C}$. Bacterial pellet were put inside the incubator to completely dry at $65^{\circ} \mathrm{C}$ for $2-3$ days. The completely dried bacterial pellets were then coated with Palladium:Gold (80:20) before subjecting to field emission scanning electron microscope for observing the change in microbial morphology. The sample preparation for field emission scanning electron microscopy was done as per accordance of Teanpaisan et al. (2014) with minor modification.

\section{Cell apoptosis by DNA fragmentation}

DNA fragmentation is considered as the biochemical hallmark of apoptosis (Halder et al. 2015). DNA fragmentation during apoptosis causes breakage of chromosomal DNA. Random degradation of DNA in bacterial cells will results in a diffuse smear upon electrophoresis of DNA. B. subtilis treated with methanolic extract of $S$. cumini were subjected to DNA fragmentation analysis according to procedure of Nagata (2000) with minor modification. Bacillus subtilis cells were incubated with lysis buffer containing SDS, Tris, EDTA for $1 \mathrm{~h}$ at room temperature. After lysis, supernatant was taken and DNA was extracted by chloroform:Isoamyl alcohol method and precipitated by ethanol. The precipitated DNA was dissolved in Tris-EDTA (TE) buffer and run on to $1.2 \%$ agarose gel stained with ethidium bromide for analysis.

\section{Molecular docking for potent target finding of $B$. subtilis MTCC 2413 \\ File preparation}

Structure files obtained from various database contains heteroatoms and sometimes even multiple copies of polypeptide chains, hence before docking ligand and macromolecule file must be processed to eliminate false positives and to get precise docking results.

\section{Ligand preparation}

3D structure of ligands was obtained from the pubchem database in sdf format which was converted into pdb format using free version of Discovery Studio tool. Structure was then modified using AutoDock Tool (ADT) version 4.2. Following modifications were made, addition of hydrogen atoms and addition of gestiger charges then file was saved in pdbqt format.

\section{Macromolecule preparation}

On the basis of cell wall cracking observed in bacterial SEM analysis macromolecule choice was restricted to only those which play role in peptidoglycan synthesis/ breakdown. Four macromolecules from B. subtilis were chosen for docking. Macromolecule 3D structures with high structural resolution were downloaded from PDB server in pdb format. Obtained structure file were modified first to remove heteroatoms along with the water molecules secondly hydrogen atoms were added to all polar atoms to satisfy the valences and then gestiger charges were added to all the amino acid residues at last. After all modifications file was saved in pdbqt format. All structural modifications were done using ADT.

\section{Docking}

Docking analysis was performed by AutoDock ver. 4.2. Docking with AutoDock requires preparation of two kind of files, gpf (grid parameter file) and dpf file (docking parameter file). Grid parameter file defines the 3D search space for every atom type of a ligand by specifying points three dimensionally in the chosen grid, as well as their spacing. Docking parameter file on the other hand contains information about the docking algorithm to be used. Firstly grid parameter files were prepared for all the possible ligand macromolecule combinations hence a total of 44 gpf files were prepared. After making gpf, 44 docking parameter files were made using Lamarckian genetic algorithm. Using these gpf and dpf file glg (grid $\log$ file) and $\mathrm{dlg}$ (docking log file) were prepared. For every ligand-macromolecule docking a total of 10 different conformations were generated which later were analysed on the basis of their binding energy and force of attraction.

\section{Results}

Antimicrobial activity of methanolic seed extracts of $S$. cumini Linn. on B. subtilis

The methanolic seed extract of S. cumini was evaluated for the antimicrobial activity against the $B$. subtilis by agar well diffusion assay, the result is given in Fig. 1 . The result showed that $B$. subtilis is susceptible against methanolic seed extract of $S$. cumini. The methanolic seed extract showed an inhibition zone of $20.03 \mathrm{~mm}$. Here in

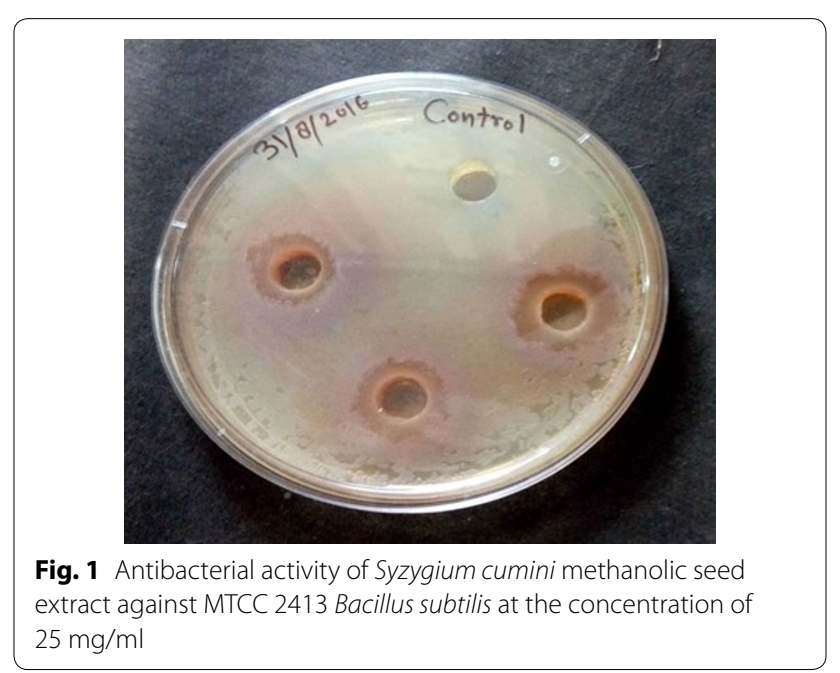


this study we attempted to understand the antibacterial mechanism behind the methanolic extract of S. cumini on B. subtilis.

\section{Minimum inhibitory concentration (MIC)}

The minimum inhibitory concentration was found to be $0.3 \mathrm{mg} / \mathrm{ml}$ with respect to control.

\section{Cell viability test}

The B. subtilis MTCC2413 was subjected to methanolic seed extract of $S$. cumini for various time interval viz. 24, 48 and $72 \mathrm{~h}$. The viability of B. subtilis was assessed by using fluorescent microscopy by staining cells with Propidium iodide (PI) at $20 \times$ magnifications. PI is commonly used as dead cell marker because live cell membrane excludes it and fluorescence is given only by dead cell whose membrane integrity is damaged. When $B$. subtilis were stained with PI red fluorescence appear as dead cell acquired the stain and appear as red colour spot when observed by fluorescence microscope (Fig. 2). Results shows the images of $B$. subtilis exposed to various time interval at the same concentration as observed by fluorescent microscope. It is clearly observed from the result that very few populations of bacterial cells were stained in control; however the population of stained bacterial cells increased with increasing time interval at the same concentration.

\section{Flow cytometric analysis for membrane permeabilization of $B$. subtilis}

The membrane permeabilization studies using PI were done on gram positive, B. subtilis. PI uptake in B. subtilis treated with methanolic seed extract of S. cumini is represented in Fig. 3a, b shows shift of mean fluorescence intensity in bar graph of 24,48 and $72 \mathrm{~h}$ of treated $B$. subtilis cells as compared to control cells. The mean fluorescence intensity of untreated cells of $B$. subtilis were found to be 254.177 while 24,48 and $72 \mathrm{~h}$ treated $B$. subtilis were found to be 314.716, 232.604 and 257.280.

The analysis revealed that seed extract has more potent membrane potential disruption activity which indicates its antimicrobial potential. The antimicrobial potential of methanolic seed extract of $S$. cumini could be restricted to inner membrane permeabilization at varying period of time.

\section{Field emission scanning electron microscope}

The B. subtilis were treated for time interval of 24,48 and $72 \mathrm{~h}$ respectively for the comparison of treated and untreated samples. The surface characterization of $B$. subtilis MTCC 2413 field emission scanning electron microscope results revealed that methanolic seed extracts of $S$. cumini induces a significant variation in the size of $B$. subtilis cells in comparison of control at $500 \mathrm{~nm}$. After $24 \mathrm{~h}$ of treatment treated cells become smaller in comparison to control. Furthermore the SEM image also revealing that after $24 \mathrm{~h}$ of incubation with $25 \mathrm{mg} / \mathrm{ml}$ of extract, morphology of $B$. subtilis is getting changed with the adherence of its extract on the surface. The size of $B$. subtilis is shrinking from its original size as compared to control and there is occurring a crack in the bacterial cell wall indicating the initialization of cell wall rupturing.

Similarly the size of B. subtilis is reduced further in ellipsoidal shape after treating it with methanolic extract of S. cumini for $48 \mathrm{~h}$. After treatment of S. cumini extract for $48 \mathrm{~h}$ a clear cracking in the bacterial cell morphology is visible. Likewise at $72 \mathrm{~h}$ of treatment of methanolic seed extract of S. cumini on the bacterial cells, the bacterial cells lost their structural identity due to the cell wall degrading ability of extract. Here it is also clearly visible

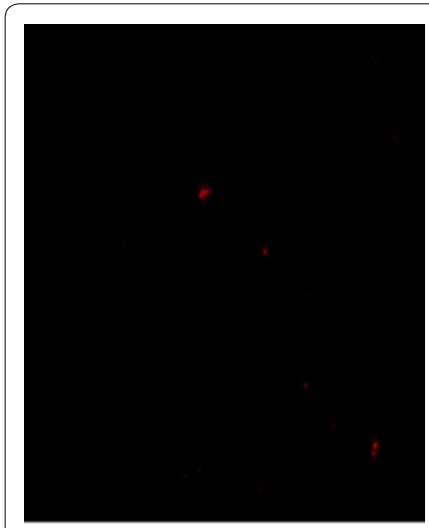

a Control

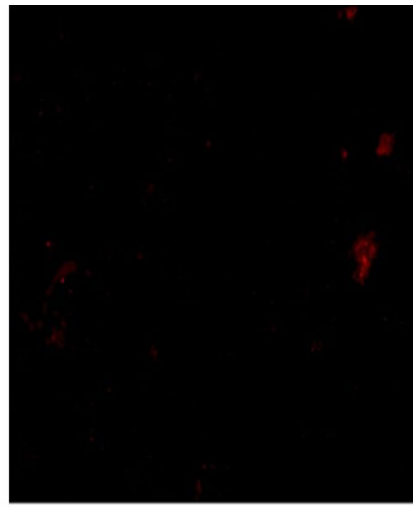

b 24 hr. treatment

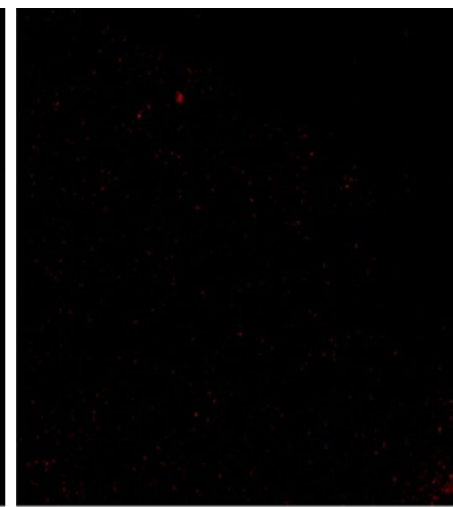

c $48 \mathrm{hr}$. treatment

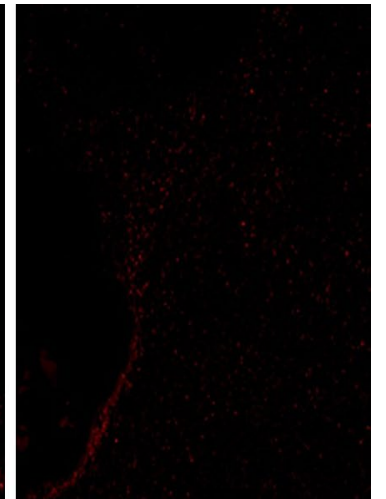

d $72 \mathrm{hr}$. treatment

Fig. 2 Fluorescence microscopy image of Bacillus subtilis stained with propidium iodide at varying period of time. $\mathbf{a}$ Control, b $24 \mathrm{~h}$ treatment, $\mathbf{c}$ $48 \mathrm{~h}$ treatment, $\mathbf{d} 72 \mathrm{~h}$ treatment 


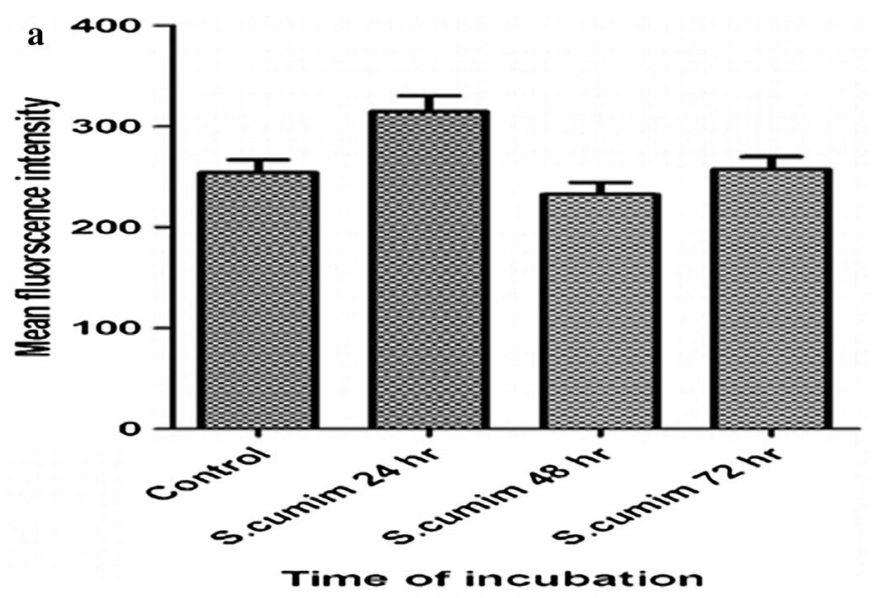

b Control

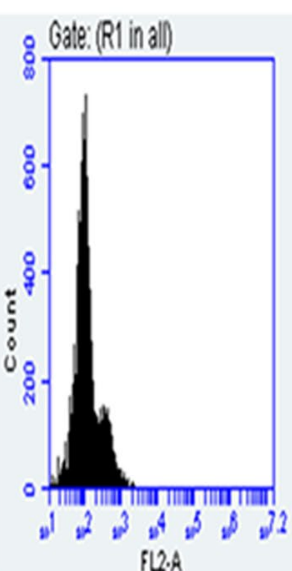

24 hours

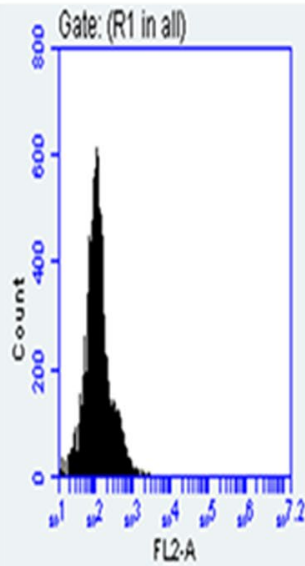

48 hours

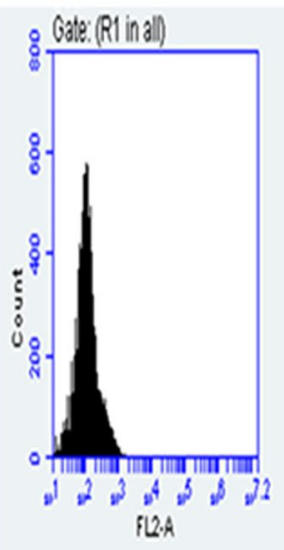

72 hours

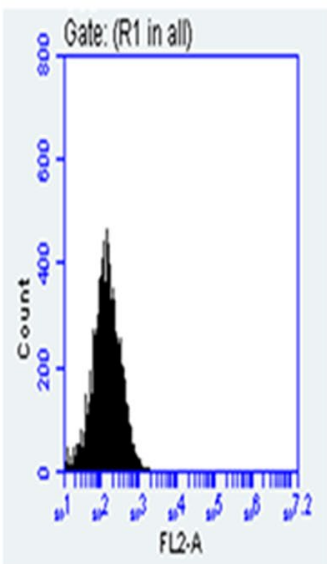

Fig. 3 a Membrane permeabilization of Bacillus subtilis MTCC 2413 by Syzygium cumini methanolic seed extract, using propidium iodide (PI) through flow cytometer technique. A total of 10,000 cells were acquired for each flow cytometric analysis. b Mean fluorescence intensity of propidium iodide in Bacillus subtilis cells exposed to Syzygium cumini on same concentration at varying period of time. b Effect of Syzygium cumini methanolic seed extract on membrane permeabilization of Bacillus subtilis :Histograms of Bacillus subtilis bacterial cells treated with Syzygium cumini methanolic seed extract for 24, 48 and $72 \mathrm{~h}$, then stained with PI and analysed by flow cytometer

that cell wall breakage in the B. subtilis after $72 \mathrm{~h}$ treatment is more as compared to 24 and $48 \mathrm{~h}$ treatment respectively as shown in Fig. 4. The SEM image clearly indicates that methanolic seed extract exert a significant antibacterial effect on bacteria. It was also reported that the extract works in a time dependent manner Images at different time intervals indicate that as exposure of time increases bacterial death increases simultaneously.

\section{Syzygium cumini induced DNA fragmentation in B. subtilis MTCC 2413}

To determine the DNA damage activity of methanolic seed extract of S. cumini in B. subtilis agarose gel electrophoresis was performed. The DNA fragmentation of methanolic seed extract of S. cumini in B. subtilis was in time dependent manner at constant concentration. No significant DNA fragmentation was observed after $24 \mathrm{~h}$ of treatment at constant concentration $25 \mathrm{mg} / \mathrm{ml}$. While after treating B. subtilis at constant concentration for $48 \mathrm{~h}$, a smear formation was observed indicating fragmentation initiation as shown in Fig. 5. Likewise on treating B. subtilis with constant concentration for $72 \mathrm{~h}$, blurred visibility of DNA smear indicating DNA fragmentation. Furthermore methanolic seed extract of $S$. cumini is revealing that during DNA fragmentation RNA impurity at the bottom is getting degraded gradually with the passage of time. This indicates that methanolic seed extract has potent activity in the degradation of RNAs of B. subtilis and inhibition of bacterial pathogenic protein synthesis also. 


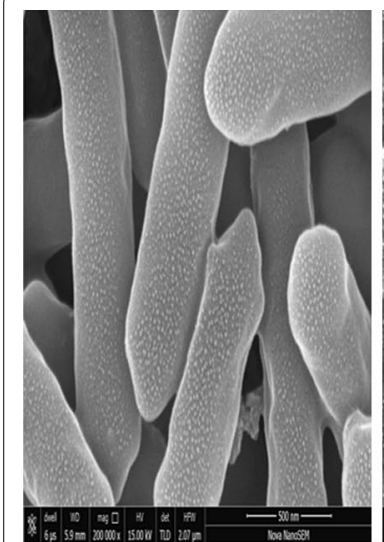

a Control

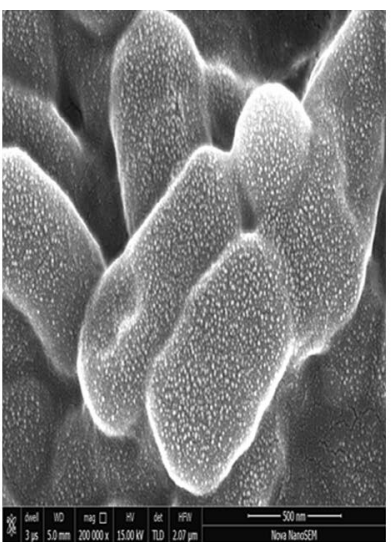

b Treated 24 hours

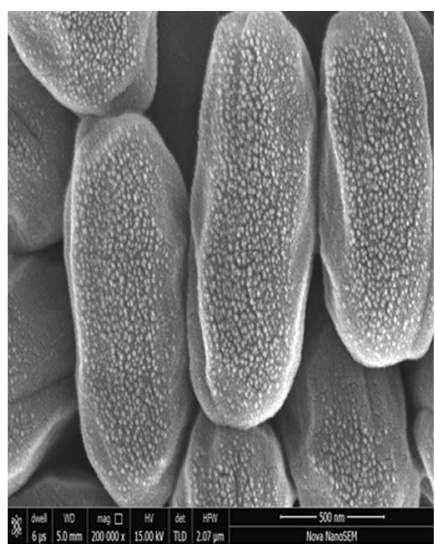

c Treated 48 hours

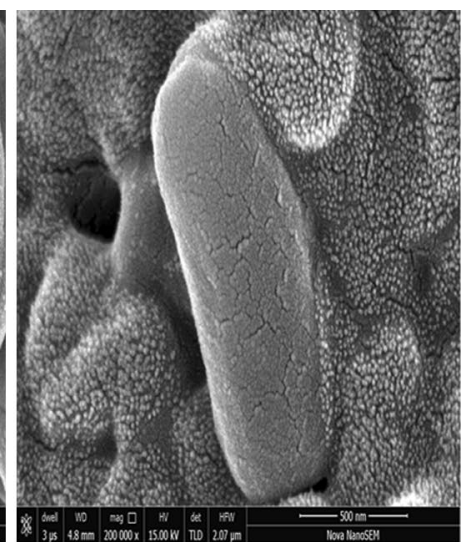

d Treated 72 hours

Fig. 4 Field emission scanning electron microscope photographs of Bacillus subtilis MTCC2413 subjecting to $25 \mathrm{mg} / \mathrm{ml}$ at various time interval of 24,48 and $72 \mathrm{~h}$. The images were taken at $500 \mathrm{~nm}$ resolution. a Control, $\mathbf{b}$ treated $24 \mathrm{~h}, \mathbf{c}$ treated $48 \mathrm{~h}, \mathbf{d}$ treated $72 \mathrm{~h}$

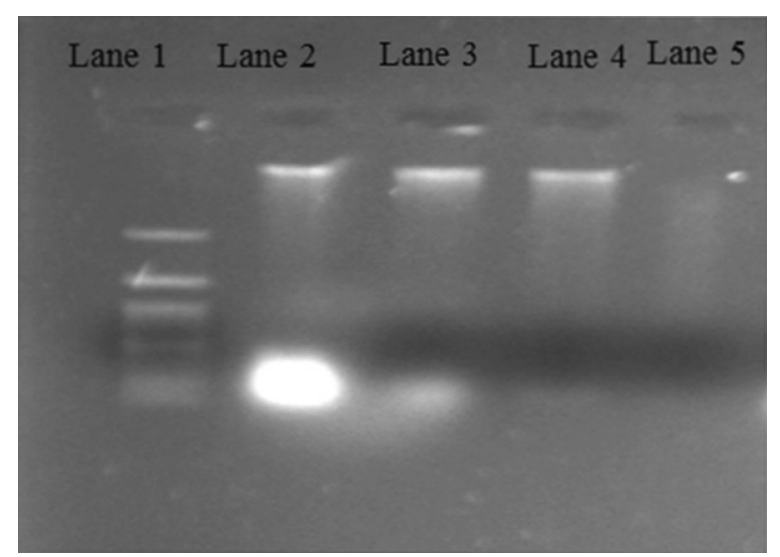

Fig. 5 Apoptotic DNA fragmentation was observable in Syzygium cumini methanolic seed extract treated Bacillus subtilis MTCC2413 Lane 1-DNA ladder, lane 2-untreated genomic DNA (control) of Bacillus subtilis MTCC2413, lane 3-treated Bacillus subtilis MTCC 2413 DNA for $24 \mathrm{~h}$, lane 4-treated Bacillus subtilis DNA MTCC 2413 DNA for 48 h, lane 5-treated Bacillus subtilis MTCC 2413 DNA for $72 \mathrm{~h}$

\section{Molecular docking}

In total 11 ligands (bioactive components in S. cumini L. methanolic extract) were selected for docking with 4 macromolecules chosen from B. subtilis. Detail of ligands and macromolecules are given in Table 1.

Docking analysis revealed that out of all the ligand chosen, lupeol showed highest binding energy for macromolecule with PDB id 1W5D and 4OX3 forming one $\mathrm{H}$-bond each, on the other hand stigmasterol and betasitosterol showed the highest binding energy for macromolecule $3 \mathrm{MFD}$ and 5E2F respectively forming 4 and $2 \mathrm{H}$-bonds as shown in Fig. 6 . These findings when combined with SEM analysis indicate that lupeol, stigmasterol and

Table 1 Macromolecules chosen from Bacillus subtilis

\begin{tabular}{lll}
\hline S. no & PDB ID & $\begin{array}{l}\text { Macromolecules } \\
\text { from Bacillus subtilis }\end{array}$ \\
\hline 1 & 1 W5D & DD-Carboxypeptidase \\
2 & $3 \mathrm{MFD}$ & $\beta$-Lactamase \\
3 & $4 \mathrm{OX} 3$ & LD-Carboxypeptidase \\
4 & $5 \mathrm{E} 2 \mathrm{~F}$ & $\beta$-Lactamase class D \\
\hline
\end{tabular}

betasitosterol somehow effect the functioning of the chosen macromolecules in bacteria effecting their functioning leading to change in peptidoglycan structure. Ligand/ macromolecule complex binding energy along with the bonding involved is given in Table 2

\section{Discussion}

In comparison to the above results following data is presented as discussed below stepwise. The antibacterial activity of S. cumini is also reported in the fruit and leaf of it in methanol, chloroform and petroleum ether over the bacterial strain of Raoultella planticola, Pseudomonas aeruginosa, B. subtilis and Agrobacterium tumifaciens and the maximum zone of inhibition was observed in $R$. plantikola $(25 \mathrm{~mm})$ followed by $B$. subtilis $(19 \mathrm{~mm}), P$. aeruginosa $(14 \mathrm{~mm})$ and $A$. tumifaciani $(12 \mathrm{~mm})$ in the methanolic extract of S. cumini leaf (Pareek et al. 2015). The methanolic fruit extract of S. cumini also showed potent antibacterial activity against these bacteria in decreasing order of activity $R$. plantikola $(21 \mathrm{~mm})<B$. subtilis $(18 \mathrm{~mm})<P$. aeruginosa $(13 \mathrm{~mm})<$ A. tumifaciani $(10 \mathrm{~mm})$. The chloroform and petroleum ether extract of $S$. cumini showed potent antibacterial property against them likewise. The antimicrobial activity of S. cumini hydro alcoholic leaf extract was 


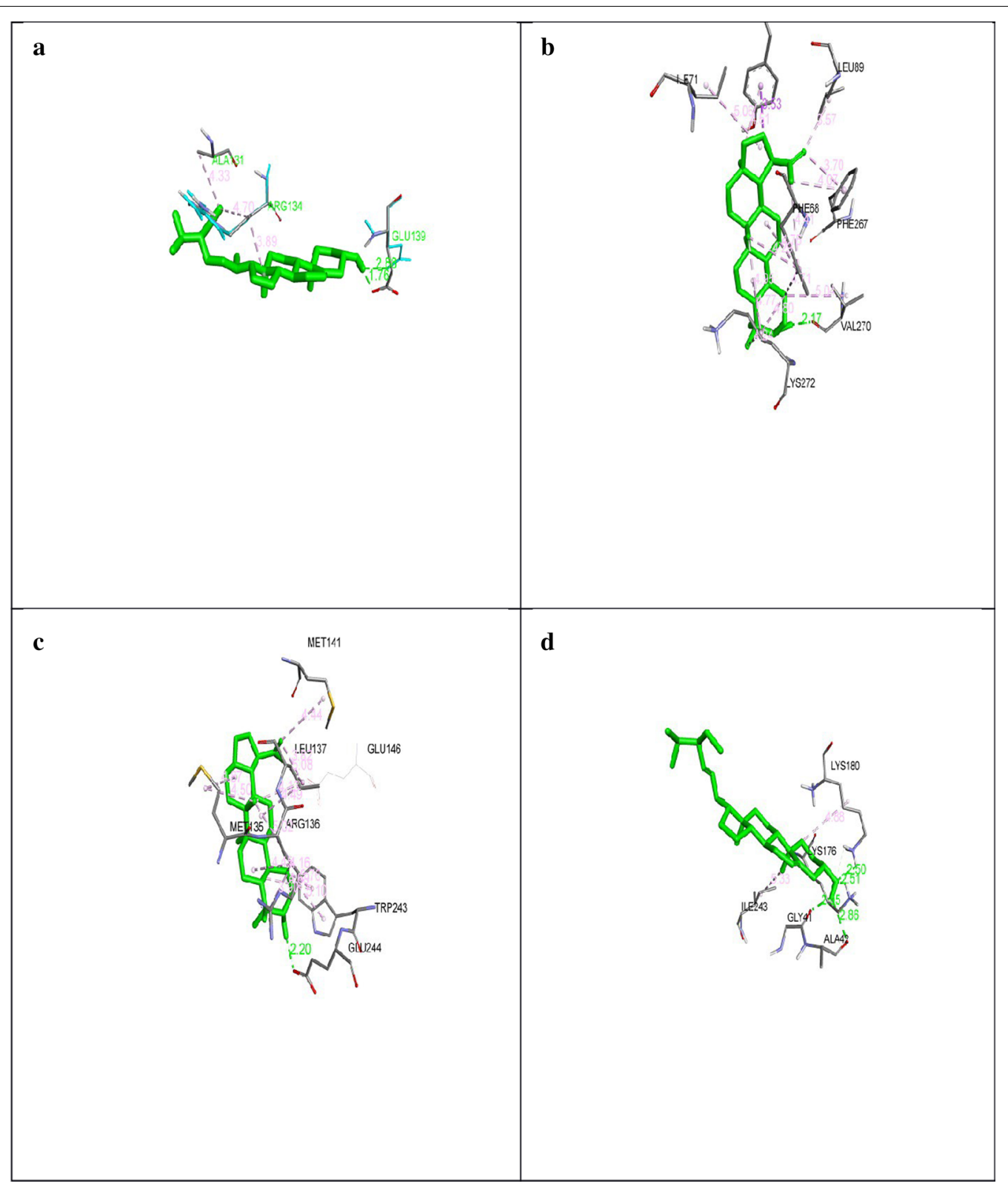

Fig. 6 Various ligand/macromolecule docking interactions a interactions between betasitosterol and 5E2F involving two H-bonds with Glu139, b indicate lupeol interaction involving one $\mathrm{H}$-bond with 4OX3, c represents interactions between lupeol and 1W5D with one H-bond, $\mathbf{d}$ represents stigmasterol and 3MFD forming four $\mathrm{H}$-bonds

also evaluated against mutli resistant strain of $P$. aeruginosa, Klebsiella pneumonia and Staphylococcus aureus and showed an inhibition zone of 10, 0.0 and $9.0 \mathrm{~mm}$ respectively (Oliveira et al. 2007). Syzygium cumini methanolic and aqueous leaf extracts were tested against some gram positive (B. subtilis and S. aureus) and gram negative bacteria (Salmonella enteritidis, Salmonella typhi A, Salmonella para typhi A, Salmonella para typhi $B$, Pseudomonas aeruginosa, E. coli) and concluded that methanolic leaf extract has more better antimicrobial activity as compared to aqueous extracts (Gowri and Vasantha 2010).

Evaluating the MIC of S. cumini also showed minimum inhibitory concentration of hydroalcoholic leaf extract of S. cumini against multi resistant strain of Pseudomonas aeruginosa was found to be $80 \mu \mathrm{mg} / \mathrm{ml}$. The MIC of methanolic fruit extract of $S$. cumini was found to be $0.18 \mathrm{mg} / \mathrm{ml}$ compared to ethyl acetate $(0.48 \mathrm{mg} / \mathrm{ml})$ and dichloromethane extract $(0.52 \mathrm{mg} / \mathrm{ml})$ of $S$. cumini fruit against Enterococcus faecalis (Priya et al. 2013). 
Table 2 Compounds from Syzygium cumini having high affinity for macromolecules from Bacillus subtilis

\begin{tabular}{|c|c|c|c|c|c|}
\hline S. no & Compound & Macromolecules from B. subtilis & Binding energy & Hydrogen bonds & Bond length $(\AA ̊)$ \\
\hline 1 & Lupeol & $1 \mathrm{~W} 5 \mathrm{D}$ & -8.48 & Glu244 & 2.20 \\
\hline \multirow[t]{4}{*}{2} & Stigmasterol & $3 M F D$ & -9.34 & Lys180 & 2.50 \\
\hline & & & & Lys176 & 2.51 \\
\hline & & & & Gly41 & 2.05 \\
\hline & & & & Ala42 & 2.86 \\
\hline 3 & Lupeol & $40 \times 3$ & -8.37 & Val270 & 2.17 \\
\hline \multirow[t]{2}{*}{4} & Betasitosterol & $5 \mathrm{E} 2 \mathrm{~F}$ & -6.42 & GLU139 & 1.76 \\
\hline & & & & GLU139 & 2.88 \\
\hline
\end{tabular}

Propidium iodide intercalates into double standard nucleic acid. It is excluded by live cells but can penetrate inside the disrupted membrane of dead cells. It is a routine parameter used for determining the apoptosis of disrupted membrane of dead cells.

Bacterial isolates treated with various concentration of chromium showed that the population of stained cells of $B$. subtilis increased with increasing concentrations of chromium as compared to control (Upadhyay et al. 2017). Brucea javanica oil induced apoptosis in T 24 cells as analysed by PI (Lou et al. 2010). Propidium iodide staining revealed that an increase in apoptosis was noticed in imatinib exposure in time and dose dependent manner on C6 glioma cells of rat (Ling et al. 2010). On the basis of these results it showed that PI staining in the present study was highly validated.

It is believed that the action of many antimicrobial agents results in the formation of pores in bacterial membrane and stimulates leakage of cellular content (Yenugu et al. 2006). The ability of methanolic seed extract of $S$. cumini to cause cellular leakage indicated that they cause pores in the bacterial membrane. The membrane damaging activity of methanolic seed extract of S. cumini is mainly accounted in the phenols and flavonoids having detergent like characteristics. The antibacterial mechanism of alcoholic extracts of Hemidesmus indicus (L.) R. Br. Ex Schult, Leucas aspera (Wild.), Plumbago zeylanica L., and Tridax procumbens (L.) R. Br. ex Schult also have shown their antimicrobial action by blebbing and leakage of cellular contents (Saritha et al. 2015). The ethanolic extract of Mentha arvensis also induce cellular damage which increased with an increase in concentration (Zhang et al. 2015). Scanning electron microscopic analysis of $S$. mutans and A. actinomycetemcomitans has revealed that cells after treatment of aqueous extract of A. lakoocha lost their original shape having an irregular, distorted cell wall structure (Teanpaisan et al. 2014). The field emission scanning electron microscope has revealed that methanolic seed extract of $S$. cumini has same antimicrobial mechanism as compared to other plant extract.

The DNA fragmentation is considered as a major key feature of programmed cell death that occurs at certain stages of necrosis. The formation of clear DNA smear in case of treated sample indicates that it shows programmed cell death after treating $B$. subtilis cells with constant concentration at 24,48 and $72 \mathrm{~h}$ as shown in Fig. 5. Pathogenic bacteria like E. coli, S. aureus and $K$. pneumonia on treatment with Caesalpinia coriaria glycosides and flavonoids for $24 \mathrm{~h}$ showed a smear of fragmented DNA (Anandhi et al. 2014). Similarly the ethanolic leaf extract of $S$. cumini after treating $V$. cholerae showed fragmented DNA after $3 \mathrm{~h}$ of treatment (Ahsan et al. 2012).

Leucas aspera, Plumbago zeylanica, Hemidesmus indicus ethanolic extract has shown potential of inner membrane permeabilization in E. coli (Saritha et al. 2015). The membrane potential disruption potential of some plants is reported such as Gracilaria tenuistipitata methanolic extract had reduced the mitochondrial membrane potential in MEGT-treated Ca9-22 cancer cells (Yeh et al. 2012). Annona muricata extract induced apoptosis in human cancer cell through disruption of mitochondrial membrane potential (Pieme et al. 2014).

Study of protein-protein or protein-receptor interactions through in silico analysis has been proved to be an efficient tool for drug designing. Similar study conducted that revealed benzofuran having high affinity for active site of COX-2 receptor showing it to be a good antiinflammatory compound (Yadav et al. 2014). Molecular docking of several compounds was performed by Valasani et al. (2014) for a potential inhibitor for cyclophilin $\mathrm{D}$, a crucial mitochondrial membrane protein. Molecular docking of methanolic seed extract of $S$. cumini with specific ligands revealed that these compounds could be used for antimicrobial agents for inhibition of B. subtilis growth. These results have provided an insight behind 
antimicrobial activity on the basis of binding energy. The binding energy of lupeol showed highest binding energy for macromolecule with PDB id 1W5D and 4OX3 forming one hydrogen bond each, on the other hand stigmasterol showed the highest binding energy for macromolecule 3MFD and 5E2F forming 4 hydrogen bonds and alkyl bonds respectively.

In conclusion, we reported that methanolic seed extract of S. cumini has potent antibacterial activity against $B$. subtilis. Although the mechanism behind the action of methanolic seed extract involves disrupting the bacterial cell wall, shrinkage in size, leaking of cellular contents. The antibacterial potential of methanolic seed extract of S. cumini can be exploited perfectly to treat infections in place of commonly used antibiotics in our day to day life. Natural replacement of chemical food preservative with herbal antimicrobial agents may provide a new and safe way to preserve the food from bacterial contamination. Futhermore, the antibacterial action of methanolic seed extract could be improved by using it in combination with natural herbal dietary phytochemicals such as phytic acid, resveratrol etc. which may increase the shelf life and control the food deterioration.

\section{Abbreviations}

PI: Propidium iodide; MTCC: Microbial Type Culture Collection; FE-SEM: Field Emission Scanning Electron Microscope; MIC: Minimum Inhibitory Concentration; ADT: AutoDock Tool; EDTA: ethylene diamine tetra acetic acid; SDS: sodium dodecyl sulphate.

\section{Authors' contributions}

Conceived and designed the experiment: NKS. Performed the experiments: AKY, SS, PS, MR, MPS. Analyzed the data: AKY, SS, MR. Contributed reagents/ materials/analysis tools: NKS. Wrote the paper: AKY and SS. All authors read and approved the final manuscript.

\section{Acknowledgements}

We are thankful to the Director Motilal Nehru National Institute of Technology Allahabad, Allahabad-211004, Uttar Pradesh, India for providing research lab and financial support for performing this experiment. Author is thankful to the Ministry of Human Resource and Development, Govt. of India, New Delhi, India for providing scholarship during this tenure.

\section{Competing interests}

The authors declare that the research was conducted in the absence of any commercial or financial relationships that could be construed as a potential competing interests.

\section{Availability of data and materials}

The data supporting the conclusions of this article are included within the article.

\section{Consent for publication}

Not applicable.

\section{Ethical approval}

This study does not contain any study with human participants or animals performed by any of the authors.

\section{Funding}

The research facility including chemicals and reagents was provided by the institution Motilal Nehru National Institute of Technology, Allahabad.

\section{Publisher's Note}

Springer Nature remains neutral with regard to jurisdictional claims in published maps and institutional affiliations.

Received: 6 September 2017 Accepted: 26 October 2017

Published online: 02 November 2017

\section{References}

Ahsan N, Paul N, Islam N, Akhand AA (2012) Leaf extract of Syzygium cumini shows anti-vibrio activity involving DNA damage. Dhaka Univ J Pharm Sci $11(1): 25-28$

Anandhi D, Srinivasan PT, Praveen GK, Jagatheesh S (2014) DNA fragmentation induced by the glycosides and flavonoids from C. coriaria. Int J Curr Microbiol Appl Sci 3:666-673

Apetroaie-Constantin C, Mikkola R, Andersson MA, Teplova V, Suominen I, Johansson T, Salkinoja-Salonen M (2009) Bacillus subtilis and B. mojavensis strains connected to food poisoning produce the heat stable toxin amylosin. J Appl Microb 106:1976-1985

Arun R, Prakash MV, Abraham SK, Premkumar K (2011) Role of Syzygium cumini seed extract in the chemoprevention of in vivo genomic damage and oxidative stress. J Ethnopharmacol 134:329-333. https://doi. org/10.1016/j.jep.2010.12.014

Collins NF, Kirshner LAM, von Holy A (1991) A characterisation of Bacillus isolates from ropy bread, bakery equipment and raw materials. S Afr J Sci 87:62-66. https://doi.org/10.1142/S0192415X10008093

Drobniewski FA (1993) Bacillus cereus and related species. Clin Microbiol Rev 6:324-338

Gowri SS, Vasantha K (2010) Phytochemical screening and antibacterial activity of Syzygium cumini (L.) (Myrtaceae) leaves extracts. Int J Pharm Tech Res 2(2):1569-1573

Halder B, Singh S, Thakur SS (2015) Withania somnifera root extract has potent cytotoxic effect against human malignant melanoma cells. PLOS ONE 10(9):e0137498. https://doi.org/10.1371/journal.pone.0137498

Kirschner LM, von Holy A (1989) Rope spoilage of bread. S Afr J Sci 85:425-427 Kramer JM, Gilbert RJ (1989) Bacillus cereus and other Bacillus species. In: Doyle MP (ed) Foodborne bacterial pathogens. Marcel Dekker, London, pp 21-70

Kumar A, Ilavarasan R, Jayachandran T, Deecaraman M, Aravindan P, Padmanabhan N, Krishan MRV (2008) Anti-diabetic activity of Syzygium cumini and its isolated compound against streptozotocin-induced diabetic rats. J Med Plants Res 2:246-249

Li Q, Korza G, Setlow P (2016) Killing the spores of Bacillus species by molecular iodine. J Appl Microbiol 122:54-64

Ling Y, Zhong-yuan XU, Xiao-hua C, Ke-wan W, Guo-feng LI, Zhi-liang C (2010) Effect of imatinib at different concentrations on rat C6 glioma cell apoptosis and cell cycle. J South Med Univ 30(5):1089-1091

Lou GG, Yao HP, Xie LP (2010) Brucea javanica oil induces apoptosis in T24 bladder cancer cells via upregulation of caspase-3, caspase-9, and inhibition of NF-KB and COX-2 expressions. Am J Chin Med 38:613

Mastan S, Chaitanya G, Latha TB, Srikanth A, Sumalatha G, Kumar KE (2009) Cardioprotective effect of methanolic extract of Syzygium cumini seeds on isoproterenol-induced myocardial infarction in rats. Der Pharm Lett 1:143-149

Nagata S (2000) Apoptotic DNA fragmentation. Exp Cell Res 256:12

Oggioni MR, Pozzi G, Valensin PE, Galieni P, Bigazzi C (1998) Recurrent septicemia in an immunocompromised patient due to probiotic strains of Bacillus subtilis. J Clin Microbiol 36:325-326

Oliveira GF, Furtado N, Filho AA, Martins JK, Cunha WR, Silva ML (2007) Antimicrobial activity of Syzygium cumini (Myrtaceae) leaves extract. Br J Microbiol 38:1517-1525

Pareek A, Meena RK, Yadav B (2015) Antimicrobial activity of Syzygium cumini. Indian J Appl Res 5(9):64-66

Pieme CA, Kumar SG, Dongmo MS, Moukette BM, Boyoum FF, Ngogang JY, Saxena AK (2014) Antiproliferative activity and induction of apoptosis 
by Annona muricata (Annonaceae) extract on human cancer cells. BMC Complement Altern Med 14:516

Priya SSL, Devi PR, Eganathan P, Kingsley J (2013) In vitro antimicrobial activity of Syzygium cumini fruit peel and identification of anthocyanins. Afr J Pharm Pharmacol 7(25):1719-1728

Rekha N, Balaji R, Deecaraman M (2008) Effect of aqueous extract of Syzygium cumini pulp on antioxidant defense system in streptozotocin induced diabetic rats. Iran J Pharmacol Ther 7:137-145

Richard V, Van der Auwera P, Snoeck R, Daneau D, Meunier F (1988) Nosocomial bacteremia caused by Bacillus species. Eur J Clin Microbiol Infect Dis 7:783-785

Saritha K, Rajesh A, Manjulatha K, Setty OH, Yenugu S (2015) Mechanism of antibacterial action of the alcoholic extracts of Hemidesmus indicus (L.) R. Br. ex Schult Leucas aspera (Wild.), Plumbago zeylanica L., and Tridax procumbens (L.) R. Br. ex Schult. Front Microbiol 6:577. https://doi. org/10.3389/fmicb.2015.00577

Sharma B, Viswanath G, Salunke R, Roy P (2008) Effects of flavonoid-rich extract from seeds of Eugenia jambolana (L.) on carbohydrate and lipid metabolism in diabetic mice. Food Chem 110:697-705. https://doi.org/10.1016/j. foodchem.2008.02.068

Tanwar RS, Sharma SB, Singh UR, Prabhu KM (2011) Antiatherosclerotic potential of active principle isolated from Eugenia jambolana in streptozotocin-induced diabetic rats. Evid Based Complement Alternat Med 2011:127641. https://doi.org/10.1155/2011/127641

Teanpaisan R, Senapong S, Puripattanavong J (2014) In vitro antimicrobial and antibiofilm activity of Artocarpus lakoocha (Moraceae) extract against some oral pathogens. Trop J Pharma Res 13(7):1149-1155

Tyagi P, Singh M, Kumari H, Kumari A, Mukhopadhyay K (2015) Bactericidal activity of curcumin / is associated with damaging of bacterial membrane. PLOS ONE 10(3):e0121313. https://doi.org/10.1371/journal.pone.0121313
Upadhyay N, Vishwakarma K, Singh J, Mishra M, Kumar V, Rani R, Mishra RK, Chauhan DK, Tripathi DK, Sharma S (2017) Tolerance and reduction of chromium(VI) by Bacillus sp. MNU16 isolated from contaminated coal mining soil. Front Plant Sci 8:778. https://doi.org/10.3389/fpls.2017.00778

Valasani KR, Vangavaragu JR, Day VW, Yan SS (2014) Structure based design, synthesis, pharmacophore modeling, virtual screening, and molecular docking studies for identification of novel cyclophilin D inhibitors. J Chem Inf Model 54(3):902-912

Valgas C, de Souza SM, Smânia EFA, Smânia A Jr (2007) Screening methods to determine antibacterial activity of natural products. Braz J Microbiol 38:369-380

Yadav P, Singh P, Tewari AK (2014) Design, synthesis, docking and anti-inflammatory evaluation of novel series of benzofuran based prodrugs. Bioorg Med Chem Lett 24(10):2251-2255

Yeh CC, Yang Jl, Lee JC, Tseng CN, Chan YC, Hseu YC, Tang JY, Chuang LY, Huang HW, Chang FR, Chang HW (2012) Anti-proliferative effect of methanolic extract of Gracilaria tenuistipitata on oral cancer cells involves apoptosis, DNA damage, and oxidative stress. BMC Complement Altern Med 12:142. https://doi.org/10.1186/1472-6882-12-142

Yenugu S, Hamil KG, French FS, Hall SH (2006) Antimicrobial actions of human and macaque sperm associated antigen (SPAG) 11 isoforms: influence of the N-terminal peptide. Mol Cell Biochem 284:25-35. https://doi. org/10.1007/s11010-005-9009-2

Zhang L, Xu S, Liang W, Mei J, Di Y, Lan H, Yang Y, Wang W, Luo Y, Huo-Wang $Z$ (2015) Antibacterial activity and mode of action of Mentha arvensis ethanol extract against multidrug resistant Acinetobacter baumannii. Trop J Pharma Res 14(11):2099-2106

\section{Submit your manuscript to a SpringerOpen ${ }^{\circ}$ journal and benefit from:}

- Convenient online submission

- Rigorous peer review

- Open access: articles freely available online

- High visibility within the field

Retaining the copyright to your article

Submit your next manuscript at $\boldsymbol{\nabla}$ springeropen.com 